\title{
FORMATION OF DNA-DAMAGING AND MUTAGENIC ACTIVITY IN THE REACTION SYSTEMS CONTAIN- ING NITRITE AND BUTYLATED HYDROXYANISOLE, TRYPTOPHAN, OR CYSTEINE
}

\author{
Masato Natake, Gen-ichi Danno, Toshikazu Maeda, \\ Kazuhiko Kawamura, and Kazuki Kanazawa ${ }^{1}$ \\ Department of Agricultural Chemistry, Faculty of Agriculture, \\ Kobe University, Nada-ku, Kobe 657, Japan
}

(Received April 2, 1979)

\begin{abstract}
Summary It was confirmed by the procedure of rec-assay that DNA-damaging activities were formed in the reaction systems containing nitrite and phenol derivatives including BHA, tryptophan or cysteine under gastric $\mathrm{pH}$ conditions. The mutagenic action of the nitrite-BHA, nitrite-tryptophan and nitrite-cysteine systems was also tested according to Ames' method using Salmonella typhimurium TA 1535 and TA 98. The mutagenic activity was observed in the nitritetryptophan and nitrite-cysteine systems, though the nitrite-BHA system did not show the activity. The DNA-damaging products were generally labile, i.e., the activity decreased significantly after 1.5 to 2 hours of the reaction, except in the case of the nitrite-BHA system. The DNAdamaging activity in the nitrite-BHA system did not decrease even after 48 hours of the reaction. Nitrosophenol derivatives themselves showed the DNA-damaging activity at $\mathrm{pH} 1$. The active product in the nitriteBHA system was isolated and the structure was determined to be 2-tertbutyl-quinone. This compound gave a positive rec-assay test, and showed no mutagenesis by Ames' method. The active product from the nitrite-cysteine system was infered to be nitrosocysteine, and the product showed both DNA-damaging and mutagenic activity.
\end{abstract}

Keywords DNA-damaging activity, mutagenesis, nitrite, BHA, tryptophan, cysteine

\section{1 名武昌人, 団野源一, 前田利和, 川村和彦, 金沢和樹}

Abbreviations: BHA, butylated hydroxyanisole; BHT, dibutylhydroxy-toluene; TLC, thin-layer chromatography; UV, ultraviolet; IR spectrum, infrared absorption spectrum; NMR, nuclear magnetic resonance; GC-MS, gas chromatography-mass spectrometry. 
It is well known that carcinogenic nitrosamines ( $N$-nitroso compounds) are formed by the reaction between secondary amines and nitrite under acidic conditions. The former are present at low concentrations in proteinaceous foods $(1-3)$ and the latter is used as a fixative to maintain the characteristic color of meat products. Therefore, chemical aspects of many studies have centered on attempts to ascertain the kinds of $N$-nitrosamines present in foods (4-6). At present we have considerable information about the formation of $\mathrm{N}$ nitrosamines, with special reference to their possible presence in foods.

In 1972, KADA et al. (7) proposed a rec-assay test in order to detect readily and efficiently the reactivity of chemical compounds with DNA in vivo. This method is based on the assumption that cells from a mutant strain $\left(\mathrm{rec}^{-}\right)$which are lacking in recombination-repairing ability for damaged DNA may be killed more than those from the wild-type strain $\left(\mathrm{rec}^{+}\right)$which does have the ability, when both strains are given a DNA-damaging product such as a carcinogenic or mutagenic compound. $\mathrm{KADA}(8)$ isolated $\mathrm{rec}^{-}$mutant ( $\mathrm{H} 45$ strain) by irradiating with $\gamma$-rays $\mathrm{rec}^{+}$strain (H 17, wild-type strain) of Bacillus subtilis, and found that the $\mathrm{rec}^{+}$strain obtained showed a stable and high susceptibility to various known carcinogens and mutagens.

On the other hand, Ames et al. $(9,10)$ described a very sensitive and simple bacterial test for detecting chemical mutagens. The compounds are tested on Petri plates with specially constructed mutants of Salmonella typhimurium as tester strains. Several tester strains were selected after screening hundreds of mutants for sensitivity and specificity in being reverted from a histidine requirement back to prototrophy by a variety of mutagens. Of the tester strains, TA 1535 can be used to detect mutagens causing base-pair substitutions and TA 98 to detect some kinds of frameshift mutagens. This procedure, Ames' method, is now widely used to detect mutagenic activity of chemical compounds, as a screening procedure for detecting chemical carcinogens.

Recently, KADA (11) found that a potential activity in their rec-assay test, a DNA-damaging activity, was developed when sorbic acid, which is currently used as an antimicrobial food additive, was heated with sodium nitrite in aqueous solution. Then, NAMIKI and KADA (12) reported that the activity was mainly caused by the formation of ethylnitrolic acid in the reaction mixture.

However, we have only scanty information as to whether C-nitroso and Snitroso compounds are also carcinogenic (DNA-damaging and mutagenic), althought their possible formation by the reaction of nitrite with phenols or sulfhydryl compounds was suggested by GILBERT et al.(13).

We also tried the rec-assay test to detect DNA-damaging activities formed by the reactions between food additives and food ingredients. During the course of the experiments, we found that the DNA-damaging activities were formed in reaction systems containing nitrite and BHA, tryptophan or cysteine under gastric $\mathrm{pH}$ conditions. The mutagenic activity was also tested by Ames' method for these three systems. The activity was found in the nitrite-tryptophan and the 
nitrite-cysteine systems, but the nitrite-BHA system showed no mutagenesis.

In this paper, the conditions of the formation of DNA-damaging activities in the reaction mixtures are described, and studies were carried out on the structure of the active products in the nitrite-BHA and the nitrite-cysteine systems. The mutagenic activity was also tested for the above three reaction systems and for the isolated active products.

\section{MATERIALS AND METHODS}

Materials. Guaranteed reagent grade of sodium nitrite, tryptophan and cysteine were used, whereas BHA and BHT were of extra pure reagent grade, from Nakarai Chemicals, Ltd., Japan. Beef extract and yeast extract powder used in culture of microorganisms for the rec-assay test were purchased from Wako Pure Chemical Ind., Japan, and from Oriental Yeast Ind., Ltd., Japan, respectively. Silica gel (Wako gel B5F) used for TLC was purchased from Wako Pure Chemical Ind., Japan. Guaranteed reagent grade of solvents from Nakarai Chemicals, Ltd., Japan, were used after redistillation.

Rec-assay. Rec-assay was conducted by the method of KADA et al. $(7,8)$. Figure 1 shows an example of the result of rec-assay conducted for water (control) and DNA-damaging (carcinogenic) substance, $N$-methyl- $N^{\prime}$-nitro- $N$ nitrosoguanidine $\left(\mathrm{CH}_{3} \mathrm{~N}(\mathrm{NO}) \mathrm{C}(: \mathrm{NH}) \mathrm{NHNO}_{2}\right)$. Overnight cultures of $\mathrm{rec}^{-}$and $\mathrm{rec}^{+}$strains in the medium supplemented with $0.1 \%$ casamino acids and $0.2 \%$ yeast extract in a basal synthetic(BS) medium(14) were diluted 10 times with the BS medium. They were streaked from small pipettes onto the surface of a broth agar plate so as not to be touching, as shown in Fig. 1. A disc paper, $8 \mathrm{~mm}$ in diameter, containing $50 \mu \mathrm{l}$ of a drug solution was placed on the plate so as to

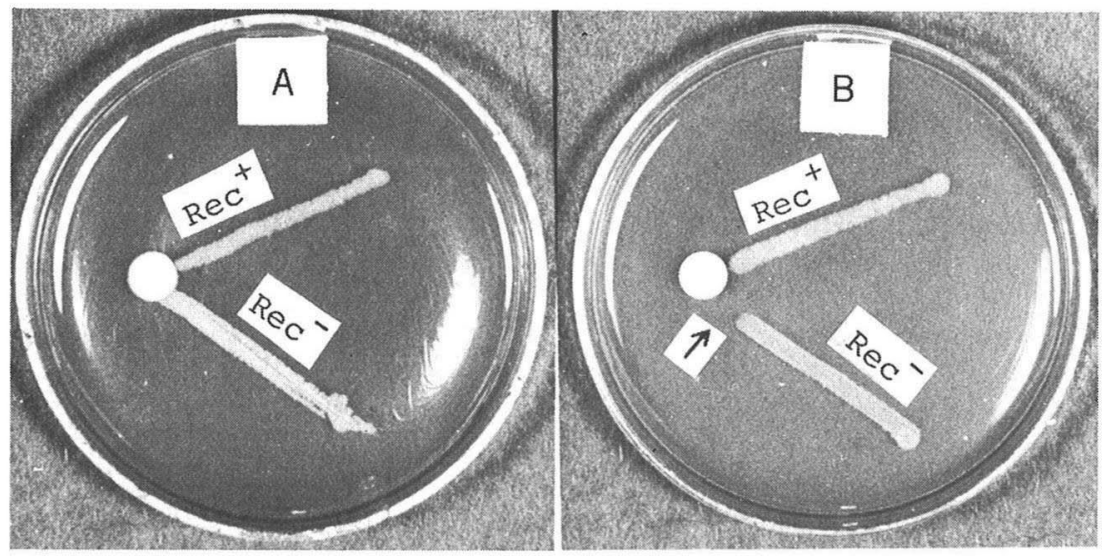

Fig. 1. An example of rec-assay. A. Fifty $\mu$ l of water was applied to disc paper. B. Fifty $\mu 1$ of $N$-methyl- $N^{\prime}$-nitro- $N$-nitroso-guanidine $(1 \mathrm{mg} / \mathrm{ml})$ was applied to disc paper. $\rightarrow$, Inhibition zone. 
cover the beginning of the bacterial streaks. By incubation for 24 hours at $37^{\circ} \mathrm{C}$, bacteria that had grown became visible, except in the inhibition zone depending on the strain and on the drug used, as shown in Fig. 1B. KADA et al.(7) described the length of the inhibition zone of $\mathrm{rec}^{-}$over that of $\mathrm{rec}^{+}$as being roughly proportional to the intensity of DNA-damaging activity of the products in the disc paper. Therefore, in the present experiments the rec-assay was conducted for the reaction mixtures containing nitrite and BHA, tryptophan or cysteine, and the difference in the length of inhibition zone between the rec ${ }^{-}$ mutant and $\mathrm{rec}^{+}$strain in the rec-assay was used as a measure of the DNAdamaging activity.

Mutagenesis assay (Ames' method). Mutagenic activity was assayed by AMEs' method(15). Stocked Salmonella typhimurium TA 1535 strain (detector of mutagens causing base-pair substitution) and TA 98 strain (detector of frameshift mutagens) requiring histidine were cultured overnight at $37^{\circ} \mathrm{C}$ in Difco broth medium containing sodium chloride, adjusted to $\mathrm{pH} 7$. Into $3 \mathrm{ml}$ of sterilized and molten top agar at $50{ }^{\circ} \mathrm{C}$ containing $0.6 \%$ agar and $0.6 \%$ sodium chloride, $0.1 \mathrm{ml}$ of the above overnight culture and $50-200 \mu \mathrm{l}$ of the reaction mixture or the isolated product solution were added. The reaction mixture added was prepared under sterile conditions, and the isolated product assayed was dissolved in sterilized distilled water. In the control, sterilized distilled water was added in place of the product solution, and sterilized sodium nitrite solution was added in place of the reaction mixture. The mixture was mixed thoroughly, then poured onto the agar plate with Vogel-Bonner minimum culture with $0.4 \%$ glucose, Difco broth $(80 \mathrm{mg} /$ liter of the culture), and biotin $(100 \mu \mathrm{g} / \mathrm{liter}$ of the culture). The plates were incubated at $37^{\circ} \mathrm{C}$ for 3 days, and the his ${ }^{+}$revertant

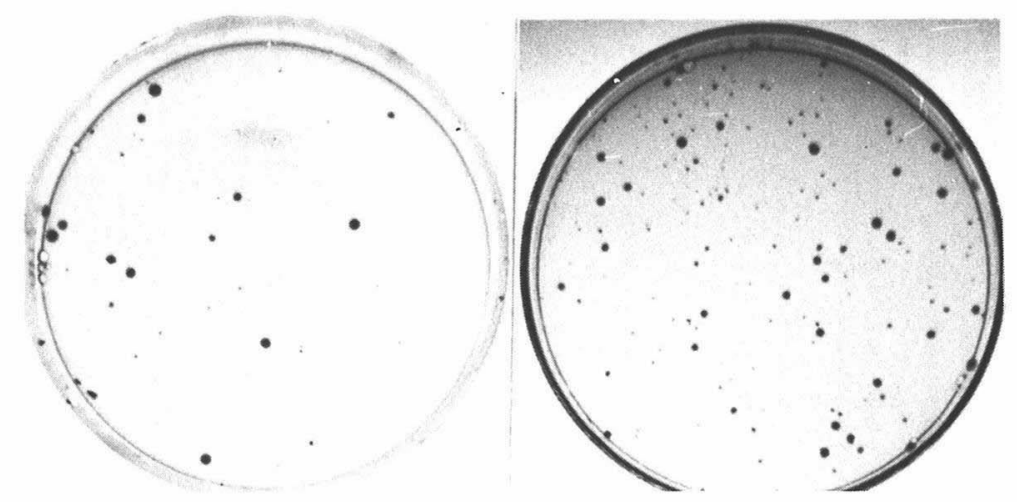

Fig. 2. An example of Ames' method for the nitrite-tryptophan system. In order to detect mutagenic activity of the system, Ames' method was conducted for $200 \mu \mathrm{l}$ of the reaction mixture containing $0.05 \mathrm{M}$ sodium nitrite and $0.025 \mathrm{M}$ tryptophan. The reaction proceeded at $\mathrm{pH} 4$ for 1 hour. Left, $200 \mu \mathrm{l}$ of $0.05 \mathrm{M} \mathrm{NaNO}_{2}$ (control); right, $200 \mu \mathrm{l}$ of the reaction mixture. More his ${ }^{+}$revertant colonies were observed in the reaction mixture than in the control. The test strain: Salmonella typhimurium TA 98. 
colonies counted. An example of the result of Ames' method conducted for the sodium nitrite solution (control) and the sodium nitrite-tryptophan reaction mixture is shown in Fig. 2.

Chromatography. Two-dimentional TLC was carried out by using the following developing solvents, (1st) hexane : ether (7:3), and (2nd) hexane: methanol $(8: 2)$ for the nitrite-BHA reaction mixture, and (1st) $n$-butanol: acetic acid : water $(4: 1: 5)$ and (2nd) benzene : acetone : methanol $(2: 1: 1)$ for the nitrite-tryptophan reaction mixture, respectively. $n$-Butanol : acetic acid : water $(4: 1: 1)$ was used in TLC of the nitrite-cysteine system. Spots of TLC were detected under visible and UV light, after spraying a suitable reagent.

Analytical methods. Sulfhydryl group was determined colorimetrically by EllmaN's reagent (16). S-Nitrosothiol (RS-NO) was determined by SAVILLE's method(17), which is based on the fact that $S$-nitrosothiol derivatives yield an equivalent of nitrous acid on mercuric ion-assisted hydrolysis, and the nitrous acid is finally used in the formation of a brilliant azo dye from sulphanilamide and $N$-1-naphthylenediamine.

Nitroso compounds also form bright green-colored complexes with the prussic salt, $\left(\mathrm{Na}_{3}\left[\mathrm{Fe}(\mathrm{CN})_{5} \mathrm{NH}_{3}\right]\right)(18)$. Thus, nitroso groups in spots on TLC were detected by spraying a freshly prepared $1 \%$ solution of prussic salt, for the nitrite-BHA and the nitrite-cysteine systems. Only the spot giving a bright green color was judged to be positive to the prussic salt test, as it was found that the salt produced a faint blue color in the presence of $p$-quinone. For detection of nitrosamine on TLC, a spray reagent described by PREUSSMANN et al.(19) was applied to the layer from the nitrite-tryptophan system. Amino group was determined by the ninhydrin method, and nitrite ion was estimated by Gries' reagent $(20)$.

Spectroscopic measurements. Mass spectrum of the active product isolated from the nitrite-BHA system was recorded on a Hitachi RMU-6MG GC-MS apparatus, by the following experimental conditions : $3 \mathrm{~mm}$ (i.d.) $\times 100 \mathrm{~cm}$ glass column, packed with $\mathrm{OV}-1(2 \%)$. Column temperature: $120^{\circ} \mathrm{C}$. Carrier gas: Helium $\left(0.3 \mathrm{~kg} / \mathrm{cm}^{2}\right)$. Ionizing voltage: $20 \mathrm{eV}$. Ionization chamber: $200^{\circ} \mathrm{C}$. Nuclear magnetic resonance spectrum of the compound was obtained with a JEOL-100 spectrometer using chloroform-D $\left(\mathrm{CDCl}_{3}\right)$ as a solvent and tetramethylsilane (TMS) as an internal standard. Infrared spectra were measured with a Hitachi EPI-S2 spectrophotometer by the $\mathrm{KBr}$ pellet method.

$p H$ adjustment. The $\mathrm{pH}$ of the reaction mixture was adjusted by adding $0.1 \mathrm{~N}$ hydrochloric acid or $0.1 \mathrm{~N}$ sodium hydroxide using a $\mathrm{pH}$-Stat.

\section{RESULTS AND DISCUSSION}

\section{Reaction of nitrite with $B H A$}

The results of rec-assay for a reaction mixture of sodium nitrite and BHA are shown in Table 1 . The DNA-damaging activity was developed at $\mathrm{pH} 1$ and 
Table 1. The formation of DNA-damaging activities in the reaction mixture containing nitrite and $\mathrm{BHA}^{\mathrm{a}}$

\begin{tabular}{lccccccc}
\hline \multirow{7}{*}{$\begin{array}{c}\text { Conc. of both } \\
\text { reactants (M) }\end{array}$} & \multicolumn{7}{c}{$\mathrm{pH}$ of reaction mixture } \\
\cline { 2 - 7 } & 1.0 & 2.0 & 3.0 & 4.0 & 5.0 & 6.0 & 7.0 \\
\hline $1 \times 10^{-2}$ each & $\mathrm{c}$ & $\mathrm{c}$ & ++ & + & - & - & - \\
$5 \times 10^{-3} \prime \prime$ & ++++ & +++ & \pm & - & & \\
$2.5 \times 10^{-3} \prime \prime$ & +++ & ++ & - & & \\
$1 \times 10^{-4} \prime \prime$ & ++ & + & - & & \\
$5 \times 10^{-4} "$ & + & - & & & & \\
\hline
\end{tabular}

a Rec-assay was conducted for $50 \mu \mathrm{l}$ of the reaction mixture, and the DNA-damaging activity was shown as the length of the inhibition zone of $\mathrm{rec}^{-}$over that of $\mathrm{rec}^{+}$. The difference of the length was expressed as follows: $0 \mathrm{~mm}(-), 0-1 \mathrm{~mm}( \pm), 1-2 \mathrm{~mm}(+), 2-3 \mathrm{~mm}(++), 3-4 \mathrm{~mm}$ $(+++)$, and $4-5 \mathrm{~mm}(+++)$.

b A 1:1 mixture of equimoles of sodium nitrite and BHA was allowed to stand at room temperature with gentle stirring.

c Neither $\mathrm{rec}^{+}$nor $\mathrm{rec}^{-}$strains could grow under these conditions.

Table 2. The relationship between the reaction time and the DNA-damaging activity formation in the nitrite-BHA system.

\begin{tabular}{ccccccc}
\hline Reaction time (min) & 5 & 15 & 30 & 60 & 90 & 120 \\
\hline DNA-damaging activity & - & \pm & + & ++ & ++ & ++ \\
\hline Reaction time (hr) & 3 & 4 & 6 & 12 & 24 & 48 \\
\hline DNA-damaging activity & ++ & ++ & ++ & ++ & ++ & ++ \\
\hline
\end{tabular}

a A 1:1 mixture (40\% ethanol solution) of equimoles of sodium nitrite and BHA was allowed to stand at room temperature with gentle stirring. Initial concentration of the reactants was $2.5 \times 10^{-3} \mathrm{M}$ each at $\mathrm{pH} 2$.

b DNA-damaging activity was expressed as described in Table 1.

2 , and at $\mathrm{pH} 3$ under a higher concentration of both reactants $\left(10^{-2} \mathrm{M}\right.$ each). The activity did not decrease even after 48 hours of the reaction at $\mathrm{pH} 2$ (Table 2).

Ames' method was also tested for $50-200 \mu$ of the nitrite-BHA reaction mixture containing $5 \times 10^{-3} \mathrm{M}$ of each reactant. The mutagenic activity, however, could not be detected in either test strain.

The thin-layer chromatogram of the nitrite-BHA reaction system maintained at $\mathrm{pH} 2$ for 20 minutes is shown in Fig. 3. The reaction mixture assumed a red color during the reaction, and seven brightly colored spots were observed on the layer without spraying any reagent. The plate was then sprayed with the prussic salt solution to detect a nitroso group, and showed no spot suggesting the presence of a nitroso group. The rec-assay was conducted for the ethanol extract 


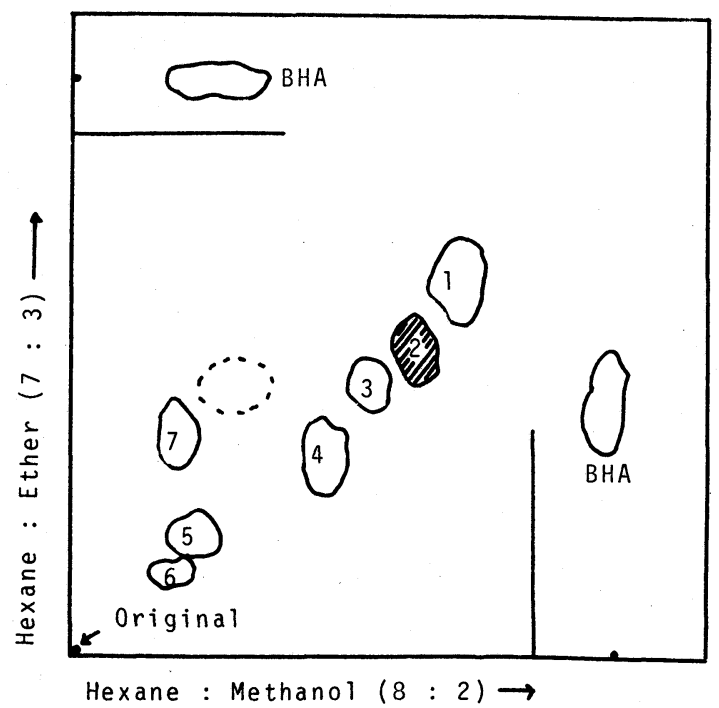

Fig. 3. TLC of the reaction mixture composed of sodium nitrite and BHA. A 1:1 mixture of $5 \times 10^{-3} \mathrm{M}$ sodium nitrite and $5 \times 10^{-3} \mathrm{M}$ BHA was maintained at $\mathrm{pH} 2$ for $20 \mathrm{~min}$, then was applied on the layer. Spots were detected by visible light and under UV light.

from each of the seven spots. The results are shown in Table 3, with the color of each spot. A compound corresponding to spot 2, which had DNA-damaging activity, was extracted by chloroform. The extract was concentrated under $\mathrm{N}_{2}$ gas, and then further purified three times by applying to TLC in the same manner. The compound on the plate was extracted by ether, and the extract was concentrated to give a crystalline product. Recrystallization of the product from ether gave 2-tert-butyl-p-quinone as yellow needles, $\mathrm{mp} 52-54^{\circ} \mathrm{C}$. Anal. Calcd.

Table 3. Rec-assay for the extract from each spot on TLC of sodium nitrite-BHA system. ${ }^{a}$

\begin{tabular}{clc}
\hline $\begin{array}{c}\text { Spot } \\
\text { No. }\end{array}$ & \multicolumn{1}{c}{$\begin{array}{c}\text { Visible } \\
\text { color }\end{array}$} & $\begin{array}{c}\text { DNA-damaging } \\
\text { activity }^{\mathrm{c}}\end{array}$ \\
\hline 1 & Yellow & \pm \\
2 & Light yellow & +++ \\
3 & Orange yellow & \pm \\
4 & Orange & - \\
5 & Dark yellow & - \\
6 & Orange red & - \\
\hline
\end{tabular}

a Rec-assay was conducted for $50 \mu \mathrm{l}$ of the ethanol extract from each spot on TLC of Fig. 3.

b The number of spots on TLC of Fig. 3.

c DNA-damaging activity was expressed as described in Table 1. 


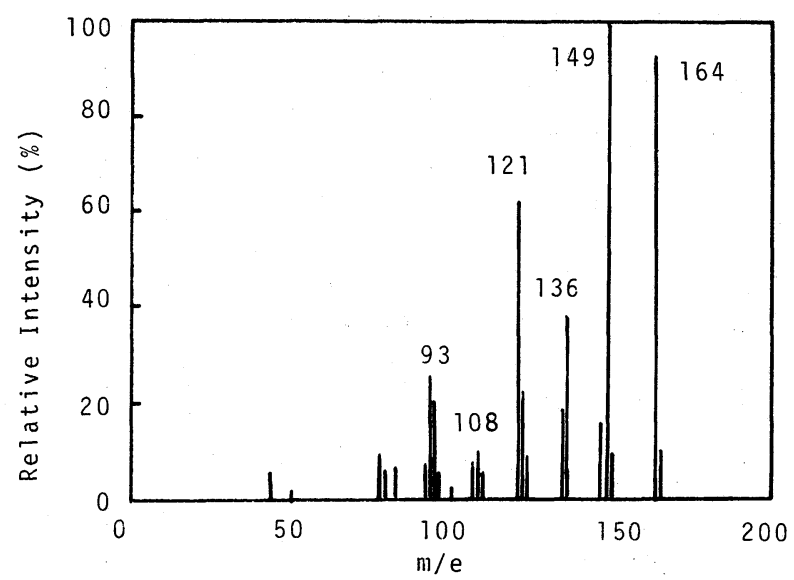

Fig. 4. Mass spectrum of the active compound isolated from the nitrite-BHA system. The experimental conditions of GC-MS are described in "Material AND Methods."

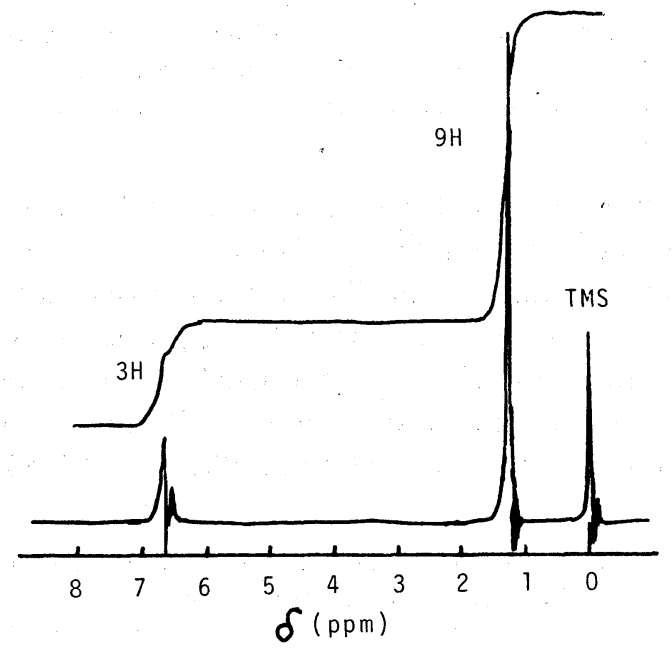

Fig. 5. NMR spectrum of the active compound isolated from the nitrite-BHA system. The experimental conditions are described in "MATERIAL AND METHODS." Sample concentration: $5 \%$.

for $\mathrm{C}_{10} \mathrm{H}_{12} \mathrm{O}_{2}, \mathrm{C} 73.15, \mathrm{H} 7.37$, O 19.49, Found, C 72.99, H 7.55, O 19.35\%. UV (nm, EtOH), $248(\varepsilon 15,600), 269(\varepsilon 1,360)$, and $420(\varepsilon 46)$. IR $\left(\mathrm{cm}^{-1}\right), 1650,1360$, $1320,1295,1005,930,840$. NMR $(\sigma), 1.25(9 \mathrm{H}), 6.62-6.66(3 \mathrm{H})$ (see Fig. 4). MS spectrum $(m / e), 164\left(\mathrm{M}^{+}\right)$(see Fig. 5).

Rec-assay test and Ames' test of the isolated compound in $50 \%$ ethanol were conducted for $50 \mu \mathrm{l}$ of $0.15-0.30 \mathrm{~mm}$ (rec-assay) and for $200 \mu \mathrm{l}$ of $0.5 \mathrm{~mm}$ (Ames' method). The results showed again the DNA-damaging activity, but no 
mutagenesis, under these conditions.

Recently, ISHIZAKI et al.(21) reported that 2-tert-butylquinone was also formed as one of the seven species of degradation products of BHA by UV irradiation.

\section{Reaction of nitrite with phenol derivatives}

Butylated hydroxyanisole is one of the phenol derivatives, and many foods contain phenol derivatives as components. Therefore, we tried rec-assay for a reaction mixture containing nitrite and phenol derivatives besides BHA. Some nitro- and nitrosophenols themselves were also rec-assayed. The results are shown in Table 4. The DNA-damaging activity developed in the reaction systems containing nitrite and phenols other than BHT. On the other hand, the tested nitrophenols themselves did not develop any DNA-damaging activity, while the nitrosophenols tested did show the activity.

Table 4. Rec-assay of phenol-sodium nitrite system, nitro- and nitrosophenols.

\begin{tabular}{|c|c|c|}
\hline $\begin{array}{l}\text { Reaction } \\
\text { system }^{a}\end{array}$ & $\mathrm{pH}$ & $\begin{array}{l}\text { DNA-damaging } \\
\text { activity }^{\mathrm{b}}\end{array}$ \\
\hline $\begin{array}{l}\mathrm{BHT} \\
\quad+\mathrm{NaNO}_{2}\end{array}$ & $1,3,5$ & - \\
\hline $\begin{array}{l}o \text {-Aminophenol } \\
+\mathrm{NaNO}_{2}\end{array}$ & 3 & + \\
\hline $\begin{array}{l}p \text {-Aminophenol } \\
+\mathrm{NaNO}_{2}\end{array}$ & 3 & + \\
\hline $\begin{array}{l}\alpha \text {-Naphthoresorcine } \\
+\mathrm{NaNO}_{2}\end{array}$ & 3 & ++ \\
\hline $\begin{array}{l}\alpha \text {-Naphthoresorcine } \\
\quad+\mathrm{NaNO}_{2}\end{array}$ & 6 & +++ \\
\hline$p$-Nitrophenol & 1 & - \\
\hline$o$-Nitrophenol & 1 & - \\
\hline$p$-Nitrosophenol & 1 & ++ \\
\hline $\begin{array}{l}\text { 4-Nitrosoresorcinol- } \\
\text { 1-monomethyl ether }\end{array}$ & 1 & + \\
\hline$\alpha$-Nitroso- $\beta$-naphthol & 1 & ++ \\
\hline
\end{tabular}

a Aqueous solutions (50 $\mu \mathrm{l}$ each) of $10^{-2} \mathrm{M}$ of each reactant were applied to disc papers of recassay.

b DNA-damaging activity was expressed as described in Table 1.

\section{Reaction of nitrite with tryptophan}

The results of rec-assay for a reaction mixture containing nitrite and tryptophan are shown in Fig. 6. The DNA-damaging activity developed at $\mathrm{pH} 2$, 3 and 4 . The activity was very labile at $\mathrm{pH} 2$ and 3 , but slightly more stable at $\mathrm{pH}$ 4. At $\mathrm{pH} \mathrm{4,} \mathrm{the} \mathrm{activity} \mathrm{remained} \mathrm{the} \mathrm{highest} \mathrm{until} 1.5$ hours of the reaction, then, decreased gradually. The mutagenic activity of the reaction mixture was 


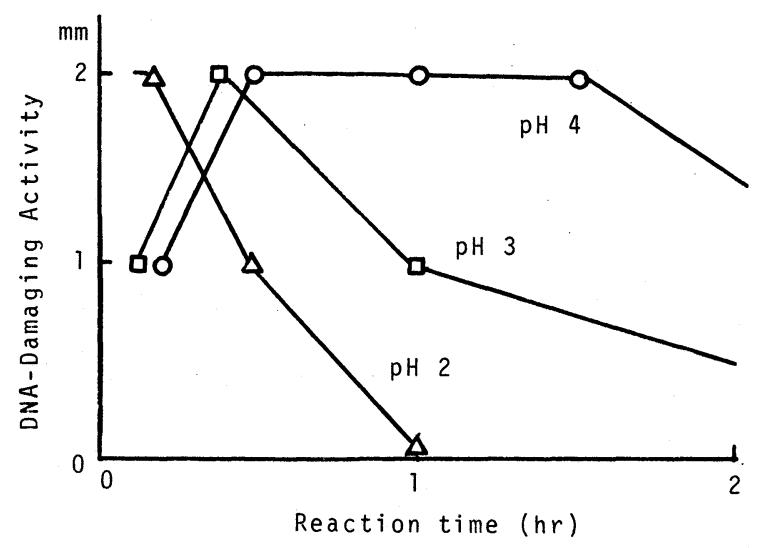

Fig. 6. Rec-assay of the reaction mixture containing sodium nitrite and tryptophan. A $1: 1$ mixture of $0.05 \mathrm{M}$ sodium nitrite and $0.05 \mathrm{M}$ tryptophan was maintained at room temperature with gentle stirring. DNA-damaging activity was expressed as the length of the inhibition zone of $\mathrm{rec}^{-}$mutant over that of $\mathrm{rec}^{+}$strain.

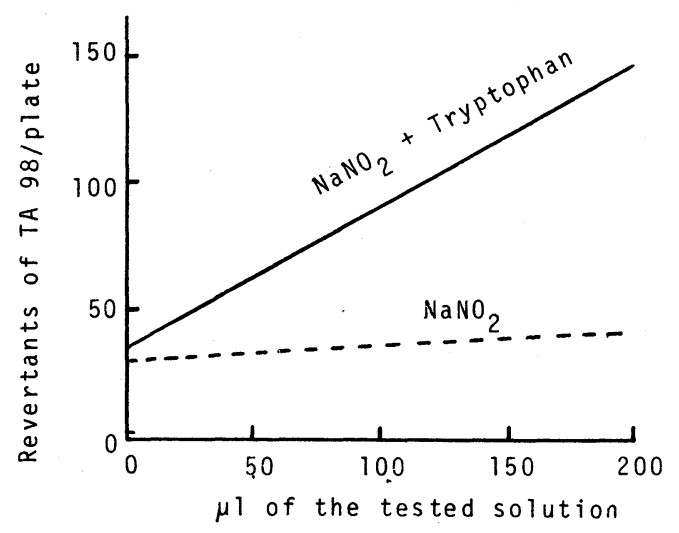

Fig. 7. Mutagenic activity of the nitrite-tryptophan system. The mutagenic activity was determined by Ames' method, for $0-200 \mu \mathrm{l}$ of the reaction mixture composed of $0.05 \mathrm{M}$ sodium nitrite and $0.025 \mathrm{M}$ tryptophan, and of $0.05 \mathrm{M}$ sodium nitrite solution. The reaction proceeded at $\mathrm{pH} 4$ for $1 \mathrm{hr}$. The test strain: Salmonella typhimurium TA 98.

tested by Ames' method. The results are shown in Fig. 2 and Fig. 7. As shown in these figures, the frameshift mutagenic activity developed, with DNAdamaging activity, by the reaction of nitrite with tryptophan at $\mathrm{pH} 4$ for 1 hour.

The thin-layer chromatogram of the nitrite-tryptophan reaction system at pH 4 for 1 hour is shown in Fig. 8. Nine spots including that of tryptophan were detected under UV light. Except for spot 8 (tryptophan), they gave a negative ninhydrin reaction, although spots 1 and 4 showed a nitrosamine reaction on the plate. Recently, we have found that the fraction obtained from silica gel column chromatography of the reaction mixture and given a positive rec-assay test gave 


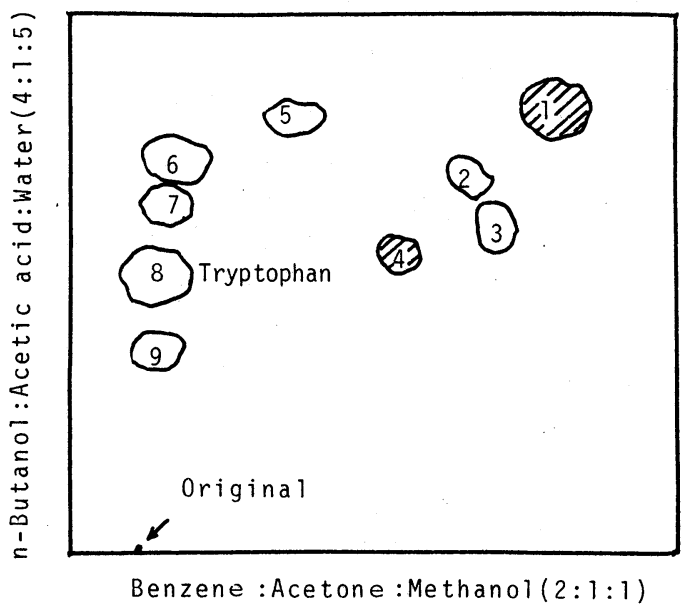

Fig. 8. TLC of the reaction mixture composed of sodium nitrite and tryptophan. A $1: 1$ mixture of $0.05 \mathrm{M}$ sodium nitrite and $0.05 \mathrm{M}$ tryptophan was allowed to stand for $1 \mathrm{hr}$ at $\mathrm{pH}$ 4 with gentle stirring, then was applied on the layer. Spots 1 and 4 gave positive nitrosamine reactions. Spots were detected under UV light.

a negative ninhydrin reaction and did not show an absorption peak at $280 \mathrm{~nm}$. Isolation and identification of the active products is in progress.

\section{Reaction of nitrite with cysteine}

The results of rec-assay for a reaction mixture containing sodium nitrite and cysteine or glutathione are shown in Fig. 9. The DNA-damaging activity developed at $\mathrm{pH} 2,3$ and 4 in the nitrite-cysteine system, and at $\mathrm{pH} 3$ in the nitrite-glutathione system. Activity in the cysteine-containing system increased with decreasing $\mathrm{pH}$. The activity, however, decreased gradually after 2 hours' reaction, and disappeared completely after 24 hours' reaction. It seems that the active product is more labile, and the reaction is specific for a sulfhydryl group. Therefore, the changes of the components of the sulfhydryl group, nitrite ion and an amino group in the reaction mixture, $\mathrm{pH} 3$, were determined during the reaction period. The results obtained are illustrated in Fig. 10. Immediately after the reaction, both sulfhydryl group and nitrite ion disappeared rapidly and correspondingly, while the content of the amino group remained unchanged. Mirna et al.(22) reported previously that nitrosothiol was formed from the reaction of sodium nitrite with a sulfhydryl compound. Figure 11 clearly shows that $0.05 \mathrm{M}$ nitrosothiol compound was formed after 30 minutes' reaction of $0.05 \mathrm{M}$ sodium nitrite with $0.05 \mathrm{M}$ cysteine. The result suggested that the molar ratio of nitrosothiol, the sulfhydryl group of cysteine, and nitrite ion might be $1: 1: 1$. However, the nitrosothiol decomposed gradually thereafter with progress of the reaction, and the DNA-damaging activity changed correspondingly with the content of nitrosothiol. Figure 12 shows that two ninhydrin-positive 


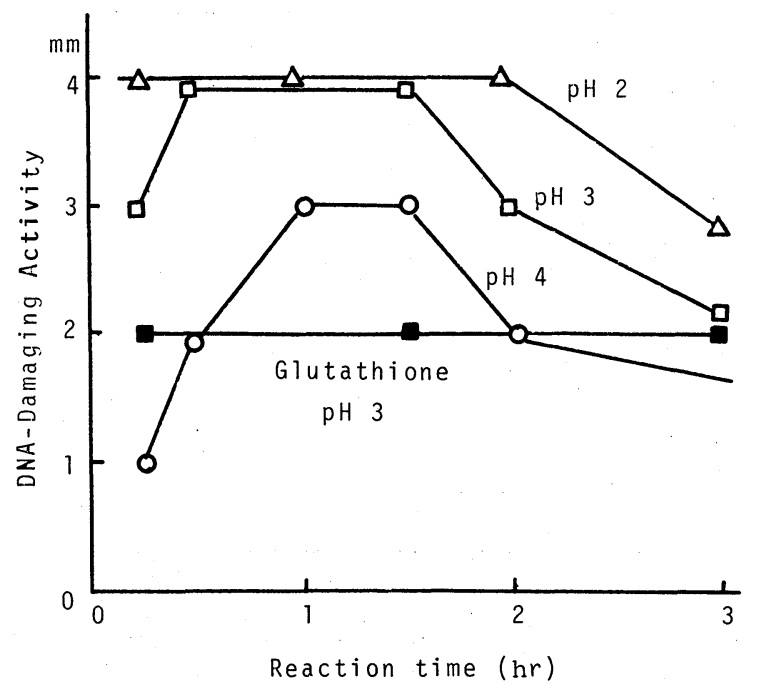

Fig. 9. Rec-assay of the reaction mixture containing sodium nitrite and cysteine. A $1: 1$ mixture of $0.1 \mathrm{M}$ sodium nitrite and $0.1 \mathrm{M}$ cysteine (or $0.1 \mathrm{M}$ glutathione) was maintained at room temperature with gentle stirring. DNA-damaging activity was expressed as noted in Fig. 6.

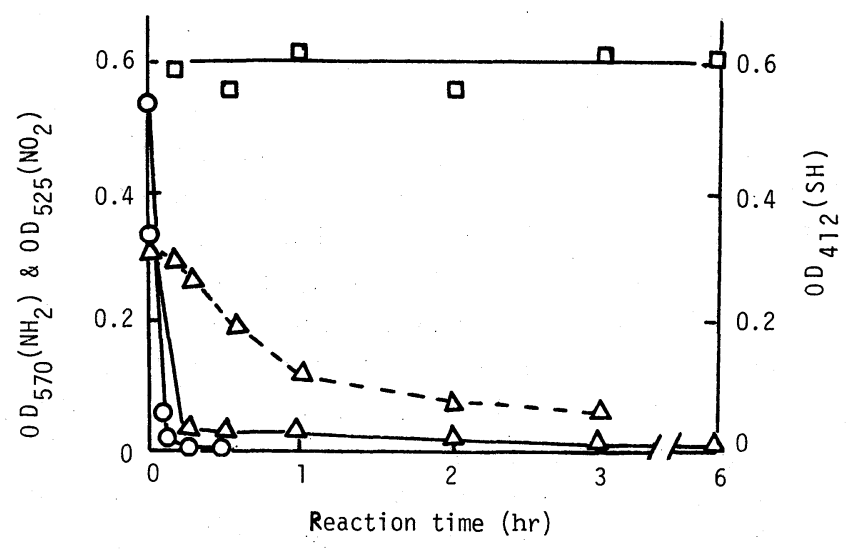

Fig. 10. Changes of contents of $-\mathrm{SH}, \mathrm{NO}_{2}{ }^{-}$and $-\mathrm{NH}_{2}$ in the reaction system composed of sodium nitrite and cysteine. A $1: 1$ mixture of $0.05 \mathrm{M}$ sodium nitrite and $0.05 \mathrm{M}$ cysteine was maintained at room temperature and at $\mathrm{pH}$ 3. $\left.\square-\square, \mathrm{OD}_{570}(-\mathrm{NH})_{2}\right) ; \bigcirc-\mathrm{O}, \mathrm{OD}_{412}(-\mathrm{SH})$; $\triangle-\triangle, \mathrm{OD}_{525}\left(\mathrm{NO}_{2}^{-}\right.$. with cysteine $) ; \triangle^{--} \triangle \mathrm{OD}_{525}\left(\mathrm{NO}_{2}^{-}\right.$without cysteine).

compounds, compound I and II, were produced in the reaction mixture containing nitrite and cysteine. Compound I, which gave a positive nitroso reaction, decreased with the reaction time, while compound II, which had the same $R_{f}$ value as cystine, increased with progress of the reaction. A spot of compound I on TLC of the 30 minutes' reaction mixture containing nitrite and 


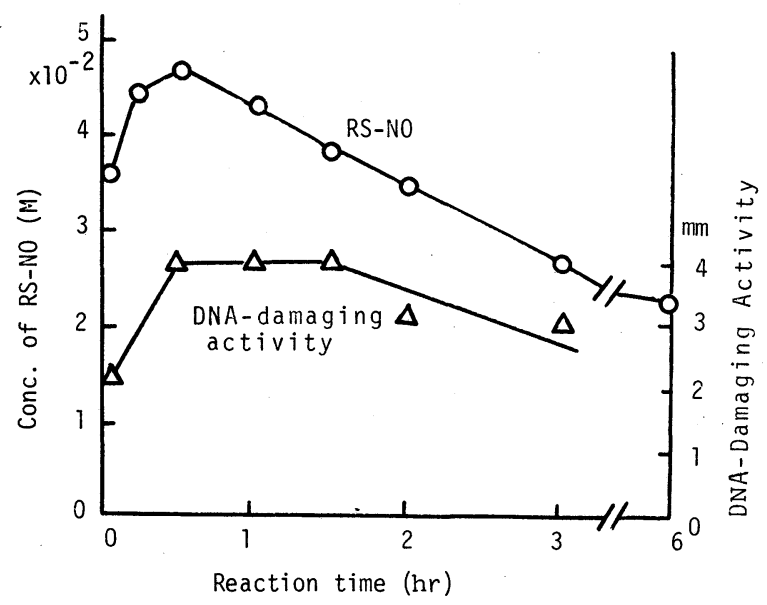

Fig. 11. Changes of nitrosothiol content and DNA-damaging activity in the reaction mixture. Original contents of sodium nitrite and cysteine were $0.05 \mathrm{M}$ each. The reaction was allowed to proceed at room temperature, $\mathrm{pH}$ 3. DNA-damaging activity was expressed as noted in Fig. 6.

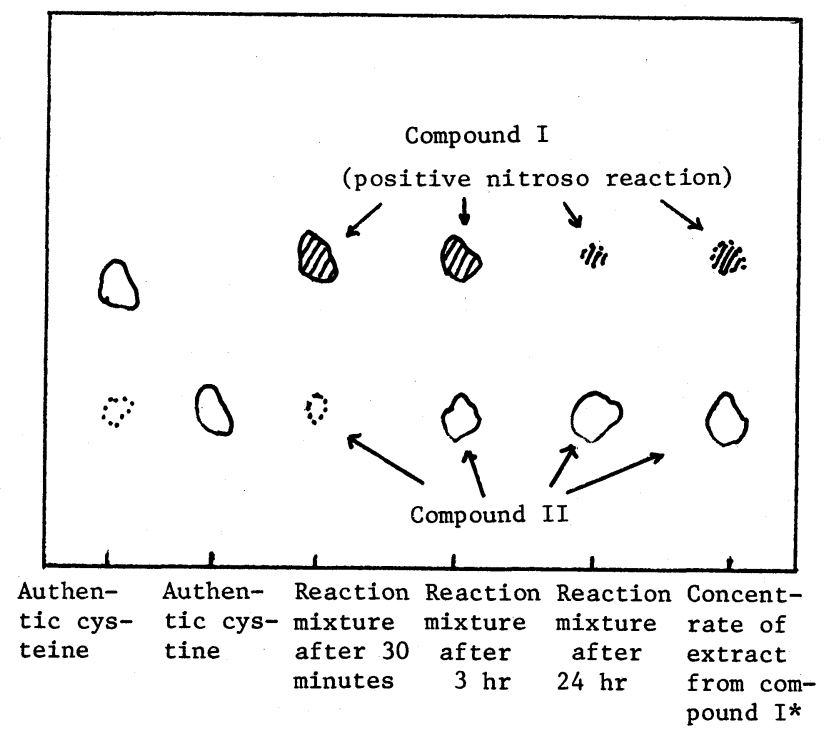

Fig. 12. TLC of the reaction mixture containing sodium nitrite and cysteine, and of an extract from compound I. A $1: 1$ mixture of $0.1 \mathrm{M}$ sodium nitrite and $0.1 \mathrm{M}$ cysteine was maintained at room temperature with gentle stirring for various times. * Compound I was extracted with $40 \%$ ethanol from another TLC of the 30 minutes' reaction mixture, then the concentrate was applied to this thin-layer plate. Ninhydrin reagent was sprayed on the plate. Rec-assay test: compound I was positive, compound II was negative. 


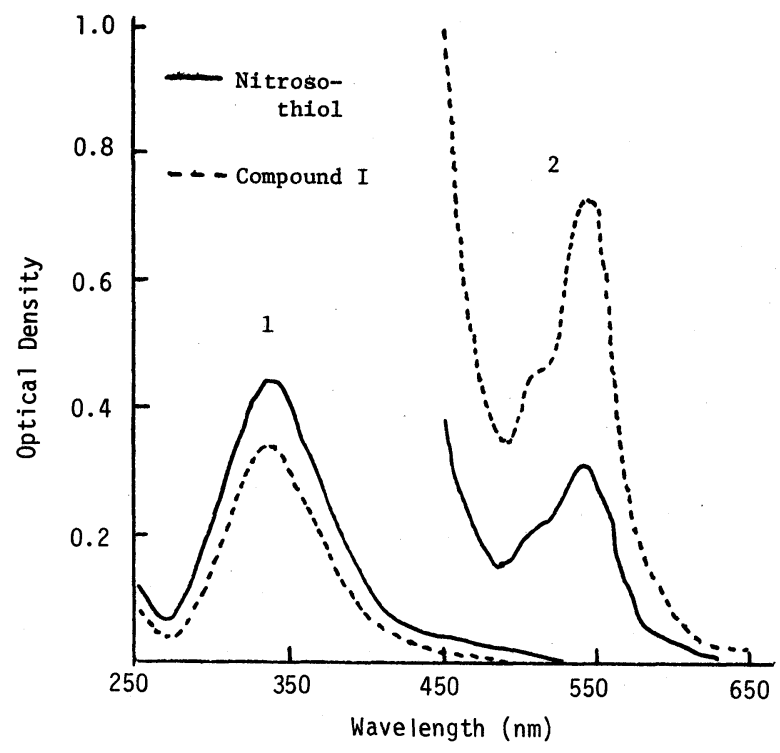

Fig. 13. Absorption spectra of nitrosothiol and compound I from cysteine and nitrite. The spectra of nitrosothiol from cysteine and nitrite cited in this figure were given by MIRNA $e t$ al. (22). The absorption spectra of compound I were determined for a $40 \%$ ethanol extract from the spot in Fig. 12. Concentration of the extract: Curve 1, ca. $0.1 \mathrm{~g}$ compound I/liter; Curve 2, ca. $5 \mathrm{~g}$ compound $\mathrm{I} /$ liter.

cysteine was extracted by $40 \%$ ethanol and concentrated. The concentrate was also thin-layer chromatographed. As shown in Fig. 12, the concentrate contained a large quantity of compound II, besides a small quantity of compound I. Thus, it seems reasonable to assume that the nitroso compound (compound I) was formed first in the reaction mixture containing nitrite and cysteine, then, the compound went on to the only final product, compound II. MiRNA et al. (22) have shown the absorption spectra of a nitrosothiol preparation $(92 \%$ pure on the basis of the NO-determination) that was precipitated by addition of acetone to a nitrite-cysteine system (Fig. 13). The $40 \%$ ethanol extract from the spot of compound I on TLC of the nitrite-cysteine system showed the same absorption spectra as the nitrosothiol from Mirna et al. (Fig. 13). On the other hand, compound II from the spot on TLC of the nitrite-cysteine system showed the same IR spectrum as authentic cystine. The reaction mixture containing nitrite and cysteine formed increasing amounts of precipitates with the reaction time at $\mathrm{pH}$ 3. Therefore, the IR spectrum of the precipitates was also determined, and the spectrum was the same as the spectra of authentic cystine and compound II. Thus, because the only final product, compound II, was confirmed to be cystine, it seems likely that compound I as a precursor of the cystine may be nitrosocysteine itself in the nitrite-cysteine system under the acidic conditions.

Rec-assay test for the extracts of compound I and II from spots on TLC 


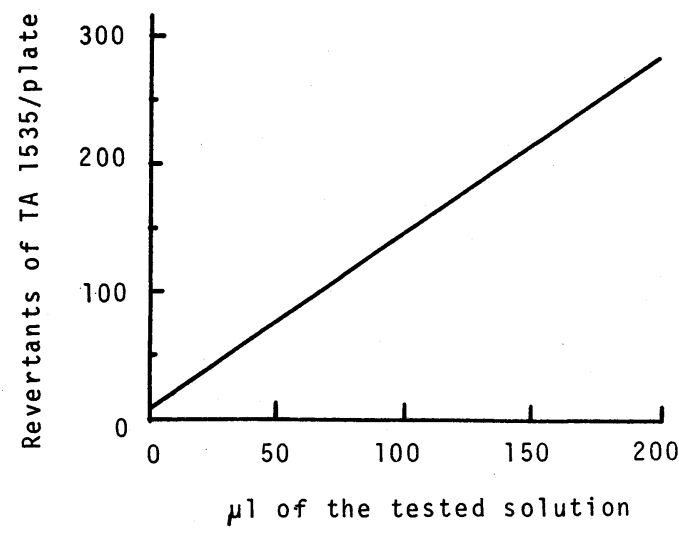

Fig. 14. Mutagenic activity of nitrosothiol (nitroso-cysteine). The mutagenic activity was determined by Ames' method, for $0-200 \mu \mathrm{l}$ of a $40 \%$ ethanol solution containing about $25 \mathrm{mg}$ of compound $\mathrm{I} / \mathrm{ml}$ of the solution. Compound I was extracted by $40 \%$ ethanol from a TLC plate of the reaction mixture composed of $0.2 \mathrm{M}$ nitrite and $0.2 \mathrm{M}$ cysteine $\cdot \mathrm{HCl}$. The reaction proceeded at $\mathrm{pH} 3$ for $1 \mathrm{hr}$. The test strain: Salmonella typhimurium TA 1535 .

clarified that compound I only had the DNA-damaging activity. Therefore, compound I was tested by Ames' method. As shown in Fig. 14, this compound is mutagenic causing base-pair substitutions. On the basis of these facts, it may be concluded that the nitrosothiol (compound I) formed in the nitrite-cysteine system may be nitrosocysteine itself and this nitrosocysteine may cause the damaging of DNA and the mutagenesis.

The authors wish to express their gratitude to Dr. Yutaka Inoue, the Public Health Institute of Hyogo Prefecture, Kobe, Japan, for kindly supplying the $\mathrm{rec}^{-}$and $\mathrm{rec}^{+}$strains for this study. We are also indebted to Dr. Tsuneo Kada, the National Institute of Genetics, Mishima, Japan, for kindly supplying the several test strains of Salmonella typhimurium, and for kind coaching on the technique of Ames' method.

\section{REFERENCES}

1) Kawamura, T., Sakai, K., Miyazawa, F., Wada, H., Ito, Y., and Tanimura, A. (1971): Studies on nitrosamines in foods. (IV). Distribution of secondary amines in foods. Shokuhin Eiseigaku Zasshi (J. Food Hyg. Soc. Jpn.), 12, 192-197.

2) Kawamura, T., Sakai, K., Miyazawa, F., Wada, H., Ito, Y., and Tanimura, A. (1971): Studies on nitrosamines in foods. (V). Distribution of secondary amines in foods (2).' Shokuhin Eiseigaku Zasshi (J. Food Hyg. Soc. Jpn.), 12, 394-398.

3) Ito, Y., Sakuta, H., TAKada, H., and TAnimura, A. (1971): Increment of secondary amines in foods by cooking or processing. Shokuhin Eiseigaku Zasshi (J. Food Hyg. Soc. Jpn.), 12, 404-407.

4) Foreman, J. K., and Goodhead, K. (1975): The formation and analysis of $N$-nitrosamines. J. Sci. Food Agric., 26, 1771-1783.

5) Sakai, A., and Tanimura, A. (1971): Studies on nitrosamines in foods. (1). In vitro and in vivo formation of dimethylnitrosamine. Shokuhin Eiseigaku Zasshi (J. Food Hyg. Soc. Jpn.), 12, $170-176$. 
6) SaKai, A., and Tanimura, A. (1971): Studies on nitrosamines in foods. (VIII). Nitrosamines detected in foods. Shokuhin Eiseigaku Zasshi (J. Food Hyg. Soc. Jpn.), 12, 485-488.

7) Kada, T., Tutikawa, K., and Sadaie, Y. (1972): In vitro and host-mediated rec-assay procedures for screening chemical mutagens; and phloxine, a mutagenic red dye detected. Mutat. Res., 16, 165-174.

8) KADA, T. (1975): Induction of DNA damage and mutations by chemicals, and their patterns; Recent studies in Bacillus subtilis. Tanpakusitsu Kakusan Koso (Protein, Nucleic Acid, and Enzyme), 20, 1123-1131.

9) Ames, B. N. (1971): in Chemical Mutagens; Principles and Methods for Their Detection, ed. by Hollaender, A., Plenum Press, New York, Vol. 1, pp. 267-282.

10) Ames, B. N. (1972): in Mutagenic Effects of Environmental Contaminations, ed. by Sutton, E. \& Harris, M., Academic Press, New York, pp. 57-66.

11) KADA, T. (1974): DNA-damaging products from reaction between sodium nitrite and sorbic acid. Annu. Rep. Nat. Inst. Genet. (Misima, Jpn.), 24, 43.

12) NAMIKI, M., and KadA, T. (1975): Formation of ethylnitrolic acid by the reaction of sorbic acid with sodium nitrite. Agric. Biol. Chem., 39, 1335-1336.

13) Gilbert, J., Knowles, M. E., and MCWeeny, D. J. (1975): Formation of C- and S-nitroso compounds and their further reactions. J. Sci. Food Agric., 26, 1785-1791.

14) KaDA, T., Noguti, T., and NAMIKI, M. (1970): Radiosensitization with iodine compounds. I. Examination of damage in deoxyribonucleic acid with Bacillus subtilis transformation system by irradiation in the presence of potassium iodide. Intern. J. Radiat. Biol., 17, 407-418.

15) Ames, B. N., McCanN, J., and YamazaKi, E. (1975): Method for detecting carcinogens and mutagens with the Salmonella/mammalian microsome mutagenicity test. Mutat. Res., 31, $347-364$

16) Ellman, G. L. (1958): A colorimetric method for determining low concentrations of mercaptans. Arch. Biochem. Biophys., 74, 443-450.

17) SAVILle, B. (1958): A scheme for the colorimetric determination of microgram amounts of thiols. Analyst, 83, 670-672.

18) FeigL, F., Translated by Oesper, R. E. (1960): Nitroso compounds (NO-group), in Spot Test in Organic Analysis, Maruzen Asian Edition, Elsevier Publishing Co., and Maruzen Co., Ltd., p. 166.

19) Preussmann, R., Daiber, D., and Hengy, H. (1964): A sensitive color reaction for nitrosamines on thin-layer chromatograms. Nature, 201, 502-503.

20) Horwitz, W. (1975): Nitrites in meat and meat products, in Official Methods of Analysis of the Association of Official Analytical Chemists, published by Association of Official Analytical Chemists, Washington, DC, p. 422.

21) Ishizaki, M., Oyamada, N., Ueno, S., Katsumura, K., and Hosogai, Y. (1978): Studies on degradation of food additives by irradiation. (III). Reaction of butyl hydroxy anisol with sodium nitrite or potassium nitrate by irradiation of ultra violet ray. Shokuhin Eiseigaku Zasshi (J. Food Hyg. Soc. Jpn.), 19, 299-304.

22) Mirna, A., and Kulmbach, K. H. (1959): Über den Verbleib von Nitrit in Fleischwaren. 1. Umsetzung von Nitrit mit Sulfhydryl-Verbindungen. Fleischwirtschaft, 49, 1361-1364. 